\title{
Application of Task-based Teaching Method to College Audio-visual English Teaching
}

\author{
Liguo Shi \\ School of Foreign Language, Wuchang Institute of Technology, \\ Wuhan Hubei, China 430065
}

\begin{abstract}
Based on the current situation of college audio-visual English teaching in China, this article points out that the avoidance in class is a serious phenomenon in the process of college audio-visual English teaching. After further analysis and combination with the characteristics of college English audio-visual teaching in China, it puts forward the application of task-based teaching method to college audio-visual English teaching and its steps, attempting to alleviate the avoidance phenomenon in students through task-based teaching method.
\end{abstract}

Keywords: task-based teaching method; college English; audio-visual English teaching

\section{Introduction}

Currently, in most colleges and universities of China, college English class unit usually consists of two classes of the same major, and that is about 60 people in one class, some even more than one hundred of people, so that the teacher feels it difficult to take some activities in the audio-visual classroom. With the low level of their English foundation, students' enthusiasm in practicing is not high. Unable to understand and speak out makes students lose their interest in English learning, so students are reluctant to take part in some activities, and avoidance phenomenon appears frequently in the classroom, thus classroom activities become a mere formality. Massive listening input and the lack of interaction between teachers and students become common phenomena in college audio-visual English teaching. In this article, the task-based teaching method is applied to college audio-visual English teaching, trying to change the avoidance phenomenon and arousing students' interest in speaking.

\section{Connotation of Task-based Teaching Method}

Task-based teaching method was first invented by an English linguist Allwright in the 1970s, popularized abroad in the 1980s, and introduced into China in the 1990s. Task-based teaching method can be regarded as one particular development within the broader "communicative approach". It is currently much discussed in many parts of the world and, indeed, is recommended in the official curriculum documents of a growing number of countries and regions. To be more specific, it means that the teachers guide language learners to complete the task of teaching in the classroom, classroom teachers inspire the interaction and communication among them so as to encourage students to use the language. In the process of completing the task of language acquisition, students ultimately achieve the goal of mastering language. Task-based teaching method is different from the traditional teaching, as the former pays attention to the information communication, activity of authenticity. Teachers should assign the successive activities, namely students complete the task and have the language acquisition in the process of conversational interaction.

British linguist Jane Willis (1996) in her book A Framework for Task-based Learning proposed three steps of teaching in task-based classroom: pre-task, task-cycle and language focus. In task-based teaching, the first thing that teachers 
need to do is to present the task, encouraging students to learn and practice under the drive of the task, and so the main purpose of the pre-task is to explain clearly the content of the task to students. Task-cycle is the central part in the implementation of task-based teaching method, during which students perform a task. Language focus is the last link of task-based teaching method, including the analysis and practice. Namely, after enough practice and students have mastered the basic skills, the teacher can let the students drill the key language points and fixed expression. With further practicing, students complete the task, acquire skills and apply the language points into the real life. The author thinks that the task-based teaching method in college audio-visual English teaching can also follow these three steps.

\section{Application of Task-based Teaching Method to College Audio-visual English Teaching}

3.1 Task preparation stage - pre-task

The role of a teacher is to introduce the theme and tasks to students and help them understand the task instructions and be prepared. When introducing the tasks, the operation process and the goal, teachers should use straightaway language and try to be specific. The purpose of this step is to arouse student's enthusiasm through assignments, and encourage the student to take part in the activities under the drive of tasks. Teachers can show pictures, videos that are associated with this unit or other forms to let the students be familiar with the topic or guess the theme of what will be learnt in advance. Take as example unit 7 Environment of College English Focus on Listening and Speaking IV. Teachers can prepare pictures related to the environment beforehand, and gradually display the pictures by the order of harmonious environment with green farmland and birds, flourishing trees being cut down, river pollution and melting ice, a set of dynamic images. After viewing the pictures, students can clearly reveal the theme of this group of pictures. In addition, teachers can also download videos or audio materials from $\mathrm{CNN}$ or VOA.

\subsection{Implementation of the task - task-cycle}

In this step, the teacher serves as a guide, while students are the masters of the class who can practice meaningful activities centered on a theme. With the help of video or audio materials, students can create a scene similar to the real communication environment and improve the students' practical ability to communicate. Classroom interaction can be performed in the form of groups, a group of two or more. The group of two is mainly involved in the situational dialogues, role-playing, discussion, etc. A group of more is the most commonly used in the big class with more than 35 students, which is more suitable for discussion, role playing, debate, brainstorming, games and other activities of intermediate or advanced stage of oral English teaching. Students are given more opportunities of oral communication in group discussion, which will enhance students' initiative and enthusiasm, help to create a harmonious emotional atmosphere, promote each team member to participate in the task through the sense of responsibility and help to carry out the individualized learning. Driven by different tasks, students form their own ways of thinking by completing a specific task, construct their own knowledge system, actively participate in various learning tasks, really do "learning by doing", gain the corresponding learning experience and enjoy their successes.

\subsection{Teaching reflection - language focus}

Teaching reflection is the last step of the task-based teaching method. After completing the required task within the prescribed time, teachers can compare and analyze the task of each group. 
The teacher should highly praise the achievements of students, and at the same time, give appropriate advice. In addition, for the important and difficult language points, the teacher can illustrate some vivid examples, which contain the new words and sentence patterns of this unit, reinforcing what they have learnt in the unit. Moreover, students should be encouraged to evaluate their role in the process of completing the task and shortcomings, even to evaluate the performance of other members of the group or other groups' members, so as to cultivate students' meta-cognitive strategy.

\section{Suggestions}

4.1 Attaching great importance to the students' individual differences and cooperation

Students' individual differences exist in any teaching method. Under the condition of multimedia task-based teaching, students are divided into several groups. Meanwhile, the students' individual differences often bring difficulty to the implementation of the task. Individual differences are various: psychological factors, habits and so on. The author also suggests taking the asynchronous task teaching method, whose advantage is that teachers can use multimedia to set up different tasks according to each student' ability. Students also have the right to select suitable tasks according to their ability.

In the task-based teaching process, students are required to work in cooperation or discuss together, which not only provides students with the chance of a lot of oral practice, but also is a process of mutual exchanges and learning. Only through mutual cooperation to complete the task can students understand the joy of overcoming difficulties and share the happiness together, so as to develop their cooperation consciousness and team spirit. After the team cooperation, students, who used to avoid participation and were reluctant to open their mouths, also form their own ideas, enhance the confidence, and overcome the negative psychology of avoidance.

\subsection{Choose the appropriate tasks}

In task-based teaching, the tasks should appear true and natural with practical significance. They are usually concerned with students' daily study, life and hobby. Therefore, in the teaching process, students are very interested in these tasks, and the interests and initiative of students are the important guarantee of the task. A sense of achievement can make students have more confidence in learning, which will in turn enhance interest in English learning. As the saying goes, interest is the best teacher, only when students show their interest in English will they have the desire to listen and express. The design of the task should follow a step-by-step process, from easy things to difficult ones, gradually broadening students' English knowledge. When students feel the joy of success, they will show their lasting learning enthusiasm and actively participate in classroom activities.

4.3 Combination of multimedia courseware and task teaching method

Based on the current teaching goal, teachers choose the appropriate task type and reasonable use of multimedia. Reasonable application of multimedia can supplement the deficiency of task teaching, promote the teaching quality, optimize the classroom teaching, cultivate students' ability and maintain the students' interest. When using multimedia, teachers should not just focus on the interesting teaching materials and stray from its center topic. As a result, they should find an appropriate way to combine multimedia and teaching content.

4.4 Strengthening interaction and emotional communication between teachers and students

Teachers must take students' emotion as an important part in the process of task-based language teaching. Teachers should help students 
fully understand that the emotional factor plays an important role in language learning, and the positive feelings will effectively promote their English learning. The positive emotion leads to positive action, which will motivate their English learning, while negative emotions hinder the progress of English learning. Positive emotions can be effectively applied to language creation practice and accelerate the speed of language acquisition and efficiency.

\section{Conclusion}

From the process of task-based teaching, the teacher's role has changed, who become the organizer and guide, and is a medium, a bridge and a partner of students, while the students are the main body in the classroom activities. In the teaching process, teachers should pass on students learning methods and skills and organize and keep the classroom fully under control at the same time. Students should be given enough exercise opportunities, so that they have the chance to fully show their talents and truly become the learning master, avoiding passive silence avoidance.

College English teaching and college English teaching reform seem to enter a bottleneck, and what we have to do is find an effective way to break through this bottleneck. The traditional teaching model and method make students learn English passively, and their initiative and enthusiasm were restrained. This article now puts forward the task-based teaching method with the purpose of mobilizing students' learning enthusiasm and initiative, attracting them to participate in the classroom tasks. The key to the successful implementation is whether we can design good tasks, which should stimulate the students' interest, mobilize and inspire all the students, make students dare and be happy to say. Therefore, in designing the teaching content, the teacher must take student interest as a starting point, and the task should be true and natural. Combining with a variety of strategies to make the students involve in the pleasant learning atmosphere, the task-based teaching method will surely improve the avoidance phenomenon in audio-visual classroom, and finally improve students' comprehensive ability.

\section{Reference}

[1] Chen Zhiyun. Formative Assessment Mode in the Design of College Audio-visual English Teaching [J]. Journal of Xiangtan Normal University, 2009(1).

[2] Crookes, G and R. Schmidt, Motivation: Reopening the Research Agenda [J]. University of Hawaii Working Papers in ESL, 1989 (8).

[3] Dong Yafen. College English Focus on Listening and Speaking[M]. Shanghai: Shanghai Foreign Language Education Press, 2016 (6).

[4] Lin Lan. Theory of Curriculum Reform of College English Audio-visual Elements [J]. Journal of Mudanjiang Normal University (Philosophy Edition), 2009 (3).

[5] Nunan, D. Designing Tasks for the Communicative Classroom[M]. Cambridge: Cambridge University Press, 1989.

[6] Wei Yonggong. Task-based Language Teaching Research $[\mathrm{M}]$. Shanghai: East China Normal University Press, 2004.

[7] Willis D. A Framework for Task-Based Learning[M]. London: Longman Press,1996. 